\title{
Blueberry husks and multi-strain probiotics affect colonic fermentation in rats
}

\author{
C. Bränning ${ }^{1}$, Å. Håkansson ${ }^{1}$, S. Ahrné ${ }^{1}$, B. Jeppsson ${ }^{2}$, G. Molin ${ }^{1}$ and M. Nyman ${ }^{1}$ \\ ${ }^{1}$ Applied Nutrition and Food Chemistry, Department of Food Technology, Engineering and Nutrition, Center for Chemistry \\ and Chemical Engineering, Lund University, P.O. Box 124, SE-221 00, Lund, Sweden \\ ${ }^{2}$ Department of Surgery, University Hospital Malmö, Lund University SE-205 02 Malmö, Sweden
}

(Received 5 February 2008 - Revised 19 June 2008 - Accepted 25 June 2008 - First published online 5 August 2008)

The aim was to investigate how blueberry husks and/or mixtures of probiotic strains (Lactobacillus crispatus DSM16743, L. gasseri DSM16737 and L. plantarum DSM15313 (LABmix), or Bifidobacterium infantis DSM15159 and DSM15161 (BIFmix)) affect colonic fermentation, caecal counts of lactobacilli, bifidobacteria and Enterobacteriaceae, body weight gain, and blood concentrations of carboxylic acids (CA) and ammonia in rats. Dietary fibres in blueberry husks were fermented to $61 \%$ in colon, and the elevated faecal excretion of fibre and protein contributed to the high faecal bulking capacity (1.3). The caecal pool of CA was higher in rats fed blueberry husks than the fibre-free control $(P<0 \cdot 05)$, and the propionic acid proportion was higher in the distal colon than in the control group $(P<0.05)$. Probiotics lowered the caecal amount of CA when added to blueberry husks $(P<0 \cdot 001)$, while the propionic acid proportion was higher with LABmix $(P<0 \cdot 01)$ than blueberry husks only. The propionic acid and butyric acid concentrations in blood were higher in rats fed blueberry husks and probiotics than those fed blueberry husks only $(P<0.01)$, implying that the absorption of these acids was facilitated by the bacteria. The caecal counts of lactobacilli, bifidobacteria and Enterobacteriaceae were lower in rats fed blueberry husks than the control diet $(P<0.05)$. The body weight gain was partly influenced by the caecal tissue and contents weights, and BIFmix decreased the ammonia concentration in blood $(P<0 \cdot 05)$. We conclude that colonic fermentation is differentially affected by dietary fibre and probiotics, which may be of importance when developing foods with certain health effects.

Blueberry husks: Dietary fibre: Probiotics: Bifidobacterium infantis: Lactobacillus crispatus: Lactobacillus gasseri: Lactobacillus plantarum: Short-chain fatty acids: Carboxylic acids: Ammonia: Weight gain

The intestinal microbiota can play an important role in health and disease, although we as yet do not have a clear picture of the contributions of different components to the maintenance of bowel health. Many intrinsic and extrinsic factors affect the constitution, including nutrients, age, immunological status of the host, transit time, competition between different bacterial species, and the presence and availability of fermentable material in the gut ${ }^{(1)}$. Components in the diet that enter the colon may exert a major influence on the bacterial populations and their activities ${ }^{(2)}$. As a consequence, modification of the microbiota has become an important objective in dietetics. The aim of probiotic therapy is to normalise the properties of unbalanced indigenous microbiota by the intake of specific strains, mostly lactobacilli or bifidobacteria. Foods containing both probiotics and dietary fibre may therefore have a potential role in influencing the gastrointestinal health.

The quantitatively most important substrates for the colonic microflora are carbohydrates such as dietary fibre, resistant starch and oligosaccharides ${ }^{(3)}$. Small amounts of protein and fat may also reach the colon, as well as polyphenols ${ }^{(4)}$. The unabsorbed dietary carbohydrates escaping digestion and absorption in the small intestine are available to the colon and become substrates for fermentation by the colonic microflora and thus have potential prebiotic effects.
The carbohydrates may be selectively metabolised by desirable moieties of the indigenous microbiota, and will thus exert prebiotic effects that change the composition and activity of the microbiota ${ }^{(5)}$. The main end-products of fermentation are SCFA, mainly acetic, propionic and butyric acid. These SCFA can be utilised by the colonic mucosa, absorbed or excreted in the faeces ${ }^{(6)}$. Butyric acid is an important energy substrate for colonic epithelial cells ${ }^{(7)}$ and also affects proliferation and differentiation ${ }^{(8)}$. The metabolism of butyric acid occurs mainly in the colonic mucosa, but during increased production butyric acid may be distributed to cells not in direct proximity to the gut $^{(9)}$ causing systemic effects. Propionic acid and acetic acid are metabolised by the liver, and it has been suggested that they have effects on lipid and glucose metabolism. Propionic acid may inhibit hepatic cholesterol synthesis from acetic acid, and the higher the propionic: acetic acid ratio, the more pronounced the effects ${ }^{(10)}$. Lactic acid, succinic acid, branched-chain fatty acids and small amounts of valeric, heptanoic and caproic acid may also be formed during fermentation. The physiological effects of these are less well-known, however, the $\mathrm{pH}$ is lowered by all SCFA, which may be beneficial per se ${ }^{(3)}$.

Phenolic compounds have been increasingly associated with various physiological effects ${ }^{(11)}$ by acting as antioxidants ${ }^{(12)}$.

Abbreviations: BIFmix, Bifidobacterium infantis DSM15159 and DSM15161; CA, carboxylic acids; CFU, colony-forming units; LABmix, Lactobacillus crispatus DSM16743, L. gasseri DSM16737 and L. plantarum DSM15313.

* Corresponding author: Dr Camilla Bränning, fax +46 46 2224532, email camilla.branning@appliednutrition.lth.se 
Polyphenols can also be toxic towards fungi, yeasts and bacteria $^{(13)}$, and their antimicrobial activity has attracted interest. Most Lactobacillus spp. are unable to degrade polyphenols, but strains of the closely related species L. plantarum, L. pentosus and $L$. paraplantarum have been shown to possess tannase activity ${ }^{(14)}$ and to metabolise phenolic acids ${ }^{(15)}$. Blueberries contain high amounts of phenolic compounds, mainly anthocyanins $^{(16)}$, and these compounds are mainly deposited in the cell wall of the berry, where lignin accumulates ${ }^{(17)}$. Blueberries also contain dietary fibre, which may have beneficial effects per se, either on the metabolism or on intestinal function.

In recent years, there has been considerable interest in the contribution of the microbiota to the pathophysiology of obesity. The intestinal microflora may affect the energy balance of the host through different mechanisms. Microbial regulation of host genes that promote lipid deposition in adipocytes may enhance the storage of TAG in fat cells ${ }^{(18)}$. The microbiota of the human intestine is often dominated by members of the bacterial phyla (divisions) known as Firmicutes and Bacteroidetes. Studies in both obese human subjects $^{(19)}$ and mice ${ }^{(19,20)}$ have shown a higher proportion of intestinal Firmicutes in the obese than in lean controls, and the relative abundance of Bacteroidetes increases as obese individuals lose weight. Lactobacillus spp. and Bifidobacterium spp. are frequently used as probiotics, the former belonging to the Firmicutes and Bifidobacterium belonging to the Actinobacteria.

The aim of the present study was to examine how blueberry husks and/or mixtures of probiotic strains (Lactobacillus crispatus DSM 16743, L. gasseri DSM 16737 and L. plantarum DSM 15313 (LABmix), or Bifidobacterium infantis DSM 15159 and DSM 15161 (BIFmix)) affect colonic fermentation, i.e. the production of carboxylic acids (CA) in the hindgut, the viable counts of lactobacilli, bifidobacteria and Enterobacteriaceae in caecum, body weight gain, and the concentrations of ammonia and SCFA in the portal blood in rats. Blueberry husks were chosen due to their high content of fibre and polyphenols, and there is a growing interest towards new materials with prebiotic potentials to be incorporated in future functional foods. The Lactobacillus and Bifidobacterium have a long tradition of being used as probiotics and the chosen species $L$. gasseri and $L$. crispatus are typically dominating in healthy vagina and, hence, seem to be the choice of nature for the primal inoculation of infants. L. plantarum is the dominating bacteria in most lactic acid-fermented foods based on plant material, and $B$. infantis is typically occurring in the colon of breast-fed infants.

\section{Material and methods}

\section{Materials}

Husks from wild-growing low-bush blueberry (Vaccinium myrtillus L.) were derived from pressed berries and then freeze-dried (Probi AB, Lund, Sweden).

The bacterial strains were Lactobacillus crispatus DSM 16743 and L. gasseri DSM 16737, both originally isolated from the healthy vagina of fertile women, $L$. plantarum DSM 15313, isolated from the gastrointestinal mucosa of a healthy human subject, and Bifidobacterium infantis DSM
15159 and B. infantis DSM 15161 , both of which have been isolated from infant faeces. The mixture of the three Lactobacillus strains is referred to in the text as the LABmix, and the two Bifidobacterium strains as the BIFmix.

The bacterial preparations were made from fresh cultures in Lactobacillus carrying medium ${ }^{(21)}$ for the Lactobacillus strains, or in bifidobacteria medium ${ }^{(22)}$ for the Bifidobacterium strains, after the following modifications per litre medium for the Bifidobacterium strains: sodium acetate, $10 \mathrm{~g}$; ascorbic acid, $10 \mathrm{~g}$; $\left(\mathrm{NH}_{4}\right)_{2} \mathrm{SO}_{4}, 5 \mathrm{~g} ; \mathrm{K}_{2} \mathrm{HPO}_{4}, 3 \mathrm{~g} ;(\mathrm{KH})_{2} \mathrm{PO}_{4}, 3 \mathrm{~g}$; Tween $80,1 \mathrm{ml}$; yeast extract, $0.5 \mathrm{~g}$; glucose, $20 \mathrm{~g}$; mineral salt solution, $5 \mathrm{ml}$. The cultures were incubated at $37^{\circ} \mathrm{C}$ in an anaerobic environment for $48 \mathrm{~h}$. The bacteria were harvested by centrifugation at $11000 \mathrm{~g}$ for $10 \mathrm{~min}$, and re-suspended in $1 \mathrm{ml}$ dilution liquid $(\mathrm{NaCl}, 8.5 \mathrm{~g} / \mathrm{l}$; bacteriological peptone (Oxoid, Unipath Ltd, Basingstoke, UK), $1 \mathrm{~g} / \mathrm{l}$; Tween $80,1 \mathrm{~g} / \mathrm{l}$; L-cysteine hydrochloride monohydrate (Merck), 0.2 g/l), before administration.

\section{Animals and diets}

Male Wistar rats (Scanbur AB, Sollentuna, Sweden), with an initial weight of $90(\mathrm{SE} 0 \cdot 8) \mathrm{g}$, were randomly divided into six groups of nine animals. The rats were housed individually in metabolic cages ${ }^{(23)}$ in a room maintained at $22^{\circ} \mathrm{C}$, with a $12 \mathrm{~h}$ light-dark cycle. The feed intake was restricted to $12 \mathrm{~g}$ (dry weight basis) per day and the water was given ad libitum. The protocol for the animal experiment was approved by the Ethics Committee for Animal Studies at Lund University. In diets containing blueberry husks this component was substituted for digestible wheat starch to give a concentration of $120 \mathrm{~g}$ dietary fibre/kg diet (dry weight basis). The wheat starch used has been shown to be completely digested in previous experiments, and therefore does not form any $\mathrm{CA}^{(24)}$. The content of dietary fibre in blueberry husks was $40 \cdot 8 \mathrm{~g} / 100 \mathrm{~g}$ (dry weight basis), and of this, $14.4 \mathrm{~g} / 100 \mathrm{~g}$ (dry weight basis) was Klason lignin, i.e. components not soluble in $12 \mathrm{M}-\mathrm{H}_{2} \mathrm{SO}_{4}$. The dietary fibre polysaccharides mainly consisted of glucose (39\%), uronic acids $(25 \%)$ and xylose $(20 \%)$. Considerable amounts of galactose $(7 \%)$ and arabinose $(5 \%)$ were also detected, while rhamnose, fucose and mannose only contributed with minor amounts $(<2 \%$; Table 1$)$.

Table 1. Composition of dietary fibre polysaccharides in blueberry husks ( $\mathrm{g} / 100 \mathrm{~g}$, dry weight basis) and faecal excretion of fibre components ( $\%$ of amount ingested) in rats fed a diet containing blueberry husks

\begin{tabular}{lcc}
\hline & Composition & Faecal excretion \\
\hline Rhamnose & $0 \cdot 4$ & 49 \\
Fucose & $0 \cdot 1$ & 39 \\
Arabinose & $1 \cdot 3$ & 27 \\
Xylose & $5 \cdot 2$ & 54 \\
Mannose & $0 \cdot 6$ & 39 \\
Galactose & $1 \cdot 8$ & 30 \\
Glucose & $10 \cdot 3$ & 46 \\
Uronic acid & $6 \cdot 7$ & 23 \\
Dietary fibre polysaccharides & $26 \cdot 4$ & 39 \\
Klason lignin & $14 \cdot 4$ & ND \\
Total & $40 \cdot 8$ & \\
\hline
\end{tabular}

ND, not determined. 
The rats were assigned one of the dietary treatments according to Table 2. A control diet without any dietary fibre or probiotics, and five test diets were prepared. In two of the test diets the LABmix or BIFmix was added to the fibre-free control diet. The other three test diets contained dietary fibre from blueberry husks and the BIFmix and the LABmix were added to two of these test diets. Viable bifidobacteria and lactobacilli were mixed daily with the feed at feeding time: $1 \times 10^{9}$ colony-forming units (CFU) for Bifidobacterium infantis DSM 15159 and B. infantis DSM 15161, and $5 \times 10^{10}$ to $1 \times 10^{11} \mathrm{CFU}$ for Lactobacillus crispatus DSM 16743, L. gasseri DSM 16737 and L. plantarum DSM 15313.

After $7 \mathrm{~d}$ of adaptation to the diets, an experimental period of $5 \mathrm{~d}$ followed, when faeces and feed residues were collected daily ${ }^{(25)}$. The faecal samples were stored at $-20^{\circ} \mathrm{C}$, thereafter freeze-dried and milled, before analysis of dietary fibre, protein, fat and ash. During the last $24 \mathrm{~h}$ of the experiment, fresh faecal samples were collected on dry ice and stored at $-40^{\circ} \mathrm{C}$ for determination of the faecal excretion of CA. After the experimental period the animals were anaesthetised by subcutaneous injection of a mixture (1:1:2) of Hypnorm (Division of Janssen-Cilag Ltd, Janssen Pharmaceutica, Beerse, Belgium), Dormicum (F. Hoffman-La Roche AG, Basel, Switzerland) and water at a dose of $0.15 \mathrm{ml} / 100 \mathrm{~g}$ body weight. The animals had been fasting for $3-6 \mathrm{~h}$ before being killed. Blood samples were collected from the portal vein, placed in tubes containing EDTA, centrifuged and stored at $-40^{\circ} \mathrm{C}$ until analysis of the SCFA, urea and ammonia. The caecum was then removed, weighed with and without its contents, and the $\mathrm{pH}$ measured in the contents, before being stored at $-40^{\circ} \mathrm{C}$ for analysis of the CA. The caecum tissue was washed with sterile PBS, weighed, collected in sterile tubes containing freezing medium and immediately frozen in liquid nitrogen for analysis of the microflora. Stool samples were collected from the proximal and distal colon and stored at $-40^{\circ} \mathrm{C}$ until the analysis of CA.

\section{Analytical methods}

The amount of soluble and insoluble dietary fibre in blueberry husks was determined gravimetrically ${ }^{(26)}$. The composition of the isolated fibre residue was analysed using GLC of the neutral sugars as their alditol acetates, and by a spectrophotometric method for the uronic acids ${ }^{(27)}$. Characterisation of fibre monomers in faeces was performed directly without any prior isolation of dietary fibre.

The protein content was analysed according to the Kjeldahl procedure, using 6.25 as the conversion factor from nitrogen to protein.

Fat was determined gravimetrically by extraction in diethyl ether and petroleum ether (bp $\left.40-60^{\circ} \mathrm{C} ; 1: 1\right)$ after hydrolysis with ethanol and $7 \cdot 7 \mathrm{M}-\mathrm{HCl}$ at $70-80^{\circ} \mathrm{C}$ for $1 \mathrm{~h}$.

The ash content was determined by combustion of the sample at $550^{\circ} \mathrm{C}$ for $24 \mathrm{~h}$.

Serum was separated from plasma before the analysis of SCFA. Calcium chloride $(1 \%, \mathrm{w} / \mathrm{w})$ and bovine thrombin (10 000 units per $6 \mathrm{ml}$ water) were added to plasma, one drop per $\mathrm{ml}$ plasma. The fibrinogen coagel was removed and the tube was centrifuged for $10 \mathrm{~min}$ at $1000 \mathrm{~g}$ with an Eppendorf Minispin centrifuge (Eppendorf AG, Hamburg, Germany).

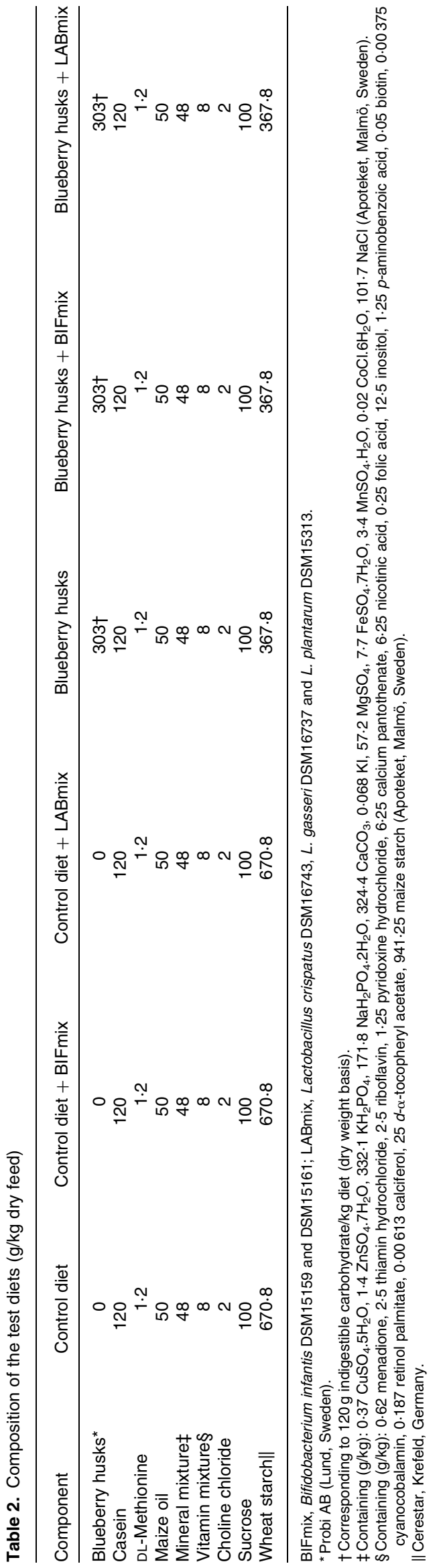


The serum was transferred to a clean tube and analysed with regard to the SCFA (acetic, propionic, isobutyric, butyric, isovaleric and valeric acids) using GLC $^{(28)}$.

Water was added to the serum samples and the SCFA were protonised with hydrochloric acid. A hollow fibre, for supported liquid membrane extraction, was immersed in the serum solution to extract the SCFA. After extraction, the SCFA were flushed from the fibre lumen and mixed with 2-ethylbutyric acid (internal standard) before being injected on to a fused-silica capillary column (DB-FFAP 125-3237; J\&W Scientific, Agilent Technologies Inc., Folsom, CA, USA). GC ChemStation software (Agilent Technologies Inc., Wilmington, DE, USA) was used for the analysis.

The SCFA (acetic, propionic, isobutyric, butyric, isovaleric, valeric, caproic and heptanoic acids) in the intestinal content (caecum, proximal and distal colon) and faeces were analysed using a GLC method ${ }^{(29)}$. The intestinal content and the faecal samples were homogenised with an Ultra Turrax ${ }^{\circledR}$ T25 basic (IKA ${ }^{\circledR}$-Werke, Staufen, Germany) after adding water. Hydrochloric acid was added to protonise the SCFA. The samples were then centrifuged (MSE Super Minor, Hugo Tillquist AB, Solna, Sweden) and 2-ethylbutyric acid (internal standard) was mixed with the supernatant before injection on to a fused-silica capillary column (see earlier). Other CA (D- and L-lactic acid and succinic acid) were quantified spectrophotometrically with commercially available enzymatic kits (numbers 11112821035 and 10176281035; Boehringer Mannheim, Mannheim, Germany). The procedures were performed according to the manufacturer's instructions.

For the analysis of ammonia sulphosalicylic acid was mixed with plasma to precipitate high-molecular weight proteins. Ammonia was determined using an amino acid analyser (Biochrom 30; Biochrom Ltd, Cambridge, UK) based on ionexchange chromatography ${ }^{(30)}$. The EZChrom Elite software package (Scientific Software Inc., Pleasanton, CA, USA) was used for the analysis.

\section{Bacteriology}

Viable counts were measured on caecal tissue, which were treated in an ultrasonic bath (Millipore, Sundbyberg, Sweden) for $5 \mathrm{~min}$ and swirled on Chiltern (Therma-Glas, Göteborg, Sweden) for $1 \mathrm{~min}$. A conventional dilution procedure was applied, and samples from the appropriate dilutions were plated. Viable counts of lactobacilli were obtained following incubation on Rogosa agar (Oxoid) anaerobically at $37^{\circ} \mathrm{C}$ for $72 \mathrm{~h}$ and Enterobacteriaceae after incubation on violet redbile-glucose agar (Oxoid), also incubated aerobically at $37^{\circ} \mathrm{C}$ for $24 \mathrm{~h}$. The bifidobacteria count was obtained by incubation on modified Wilkins-Chalgren agar (Oxoid) ${ }^{(31)}$ incubated at $37^{\circ} \mathrm{C}$ for $72 \mathrm{~h}$. Colonies from the lactobacilli count of the LABmix and the LABmix/blueberry groups (five isolates and thirteen isolates, respectively) were picked and typed with randomly amplified polymorphic DNA (see later).

For the randomly amplified polymorphic DNA method selected colonies were cultured on Rogosa agar (Oxoid) to verify their purity and to provide a template for the PCR, crude cell extract was used ${ }^{(32)}$. The primer used in the amplification was a 9-mere with the sequence $5^{\prime}$-ACG CGC CCT-3' (Scandinavian Gene Synthesis AB, Köping, Sweden) ${ }^{(32)}$. PCR templates $(1 \mu \mathrm{l})$ were used in a total reaction volume of $50 \mu \mathrm{l}$ containing PCR reaction buffer with $1.5 \mathrm{~mm}-\mathrm{MgCl}_{2}, 0.2 \mathrm{~mm}-$ dNTP and 2.5 units of Taq DNA polymerase (all from Roche Diagnostics GmbH, Mannheim, Germany). PCR amplification was performed in a Perkin-Elmer thermal cycler, using the following temperature profile: $94^{\circ} \mathrm{C}$ for $45 \mathrm{~s}, 30^{\circ} \mathrm{C}$ for $120 \mathrm{~s}, 72^{\circ} \mathrm{C}$ for $60 \mathrm{~s}$, for four cycles, followed by $94^{\circ} \mathrm{C}$ for $5 \mathrm{~s}, 36^{\circ} \mathrm{C}$ for $30 \mathrm{~s}$ (with an extension of $1 \mathrm{~s}$ per cycle), and $72^{\circ} \mathrm{C}$ for $30 \mathrm{~s}$, for twenty-six cycles. The PCR reaction was terminated at $72^{\circ} \mathrm{C}$ for $10 \mathrm{~min}$, followed by cooling to $4^{\circ} \mathrm{C}$. Agarose gel electrophoresis was run, the gels were then stained with ethidium bromide and photographed under UV illumination.

\section{Calculations and statistical evaluation}

The design of the experiment was completely randomised and resulted in a control diet containing neither dietary fibre nor probiotics. The five test diets contained either blueberry husks and/or the LABmix or BIFmix. Data from rats given diets containing probiotics were compared with those fed the control diet or the diet containing blueberry husks. Rats given blueberry husks were compared with those given the control diet without any dietary fibre. All analyses were performed at least in duplicate. The maximum error in the analyses was $<5 \%$.

Caecal pools ( $\mu \mathrm{mol})$ of CA were calculated as the concentration of each acid $(\mu \mathrm{mol} / \mathrm{g})$ multiplied by the amount of caecal content. The values were extrapolated to the complete intake of dietary fibre $(7.2 \mathrm{~g})$ to correct for the small amounts of feed residues. Body weight gain during the experimental period was calculated per $\mathrm{g}$ feed consumed. Bulking capacity was calculated as

$$
\left(\frac{\text { faecal dry weight }_{\text {test diet }}-\text { faecal dry weight }}{\text { control diet }_{\text {tietary fibre ingested }}}\right)
$$

and the fermentability of the dietary fibre was calculated as

$$
\left(1-\frac{\mathrm{g} \text { fibre in faeces }}{\mathrm{g} \text { tibst diet }}\right) \times 100 .
$$

The results were normally distributed with the exception of ammonia, and they are presented as means and standard errors in Tables 3-6. Two-way ANOVA was used to determine the effects of dietary fibre (Fibre), probiotics (Pro) and their interactions (Fibre $\times$ Pro) (Tables 3, 5 and 6). When significant differences were found, individual means were analysed by one-way ANOVA, to assess the effect of dietary fibre by using Tukey's procedure $(P<0.05)$ or the probiotic effect by using Dunnett's procedure $(P<0 \cdot 05$; Tables 3,5 and 6$)$. In Table 4 mean values of dietary intake, faecal wet weight and total faecal dry weight were analysed by one-way ANOVA using the General Linear Model procedure $(P<0 \cdot 05)$. All evaluations, except those concerning the bacterial flora, were performed with Minitab statistical software (Release 14).

The intestinal bacterial flora values are presented as medians with 25 and 75 percentiles, and statistical analyses were conducted in SigmaStat ${ }^{\circledR}$ version 3.0 (SPSS Inc., Chicago, IL, USA) (Fig. 1). Differences between the bacterial counts in all groups were evaluated using the KruskalWallis test $(P<0 \cdot 05)$. When comparing only two groups, the 
Table 3. Body weight gain, bulking capacity, caecal content, caecal pH and ammonia concentrations in rats fed a control diet without any fibre or a diet containing blueberry husks, and the same diets supplemented with bifidobacteria (BIFmix) or lactobacilli (LABmix)§

(Mean values with their standard errors for nine rats per group)

\begin{tabular}{|c|c|c|c|c|c|c|c|c|c|c|c|c|c|c|c|}
\hline & \multicolumn{2}{|c|}{ Control diet $(n 8)$} & \multicolumn{2}{|c|}{$\begin{array}{l}\text { Control diet }+ \\
\text { BIFmix }\end{array}$} & \multicolumn{2}{|c|}{$\begin{array}{l}\text { Control diet }+ \\
\text { LABmix }\end{array}$} & \multicolumn{2}{|c|}{ Blueberry husks } & \multicolumn{2}{|c|}{$\begin{array}{c}\text { Blueberry husks }+ \\
\text { BIFmix }\end{array}$} & \multicolumn{2}{|c|}{$\begin{array}{c}\text { Blueberry husks }+ \\
\text { LABmix }\end{array}$} & \multicolumn{3}{|c|}{$P$} \\
\hline & Mean & SE & Mean & SE & Mean & SE & Mean & SE & Mean & $\mathrm{SE}$ & Mean & $\mathrm{SE}$ & Fibre & Pro & Fibre $\times$ Pro \\
\hline Feed intake $(\mathrm{g} / \mathrm{d})$ & $11.5^{\mathrm{a}}$ & 0.0 & $11 \cdot 9^{\star \star}$ & 0.1 & 11.4 & 0.1 & $11 \cdot 8^{\mathrm{b}}$ & 0.0 & 11.8 & 0.0 & $11 \cdot 4^{*}$ & 0.1 & - & - & - \\
\hline Body weight gain (g/g feed)\| & $0.37^{\mathrm{a}}$ & 0.02 & 0.35 & 0.05 & 0.34 & 0.03 & $0.44^{\mathrm{b}}$ & 0.03 & $0.34^{\star}$ & 0.02 & $0.30^{\star \star}$ & 0.03 & NS & $<0.05$ & NS \\
\hline Caecal content $(\mathrm{g})$ & $1 \cdot 10^{\mathrm{a}}$ & 0.05 & 1.07 & 0.07 & $1 \cdot 31^{*}$ & 0.06 & $3.79^{\mathrm{b}}$ & 0.16 & 3.41 & 0.17 & $2 \cdot 88^{\star \star}$ & 0.18 & $<0.001$ & $<0.05$ & $<0.001$ \\
\hline Caecal tissue weight (g) & $0.39^{\mathrm{a}}$ & 0.01 & $0.58^{\star}$ & 0.05 & 0.38 & 0.01 & $0.81^{b}$ & 0.03 & 0.80 & 0.02 & $0 \cdot 70^{\star \star}$ & 0.02 & $<0.001$ & $<0.001$ & $<0.01$ \\
\hline Caecal pH & $7 \cdot 0$ & 0.1 & $7 \cdot 2$ & 0.1 & 6.9 & 0.0 & 6.7 & 0.2 & $6 \cdot 7 \dagger$ & 0.1 & $7 \cdot 0$ & 0.1 & $<0.01$ & NS & $<0.05$ \\
\hline $\begin{array}{l}\text { Bulking capacity } \\
\text { (g/g fibre ingested) }\end{array}$ & - & & - & & - & & $1 \cdot 3$ & 0.0 & 1.4 & 0.0 & 1.4 & 0.1 & - & - & - \\
\hline Fermentability (\%) & - & & - & & - & & $61 \cdot 1$ & 1.8 & 61.4 & $1 \cdot 1$ & 59.8 & 2.4 & - & - & - \\
\hline Ammonia $(\mathrm{mmol} / \mathrm{l}) \uparrow$ & 0.49 & $0.36-0.65$ & $0.32 \dagger$ & $0.30-0.40$ & 0.58 & $0.36-0.72$ & 0.45 & $0.34-0.82$ & $0.33 \ddagger$ & $0.28-0.49$ & 0.38 & $0.26-0.57$ & - & - & - \\
\hline Urea $(\mathrm{mmol} / \mathrm{l})$ & 0.58 & 0.19 & 0.44 & 0.09 & 0.49 & 0.10 & 0.79 & 0.26 & 0.41 & 0.09 & 0.47 & 0.08 & NS & NS & NS \\
\hline
\end{tabular}

BIFmix, Bifidobacterium infantis DSM15159 and DSM15161; LABmix, Lactobacillus crispatus DSM16743, L. gasseri DSM16737 and L. plantarum DSM15313.

a,b Mean values of control and blueberry husk only, i.e. those without any added probiotics, with unlike superscript letters were significantly different $(P<0.05)$.

Mean values were significantly different from those of rats fed diets without bacteria: ${ }^{*} P<0.05,{ }^{\star *} P<0.01$

Mean values were significantly different from those of the control diet: $\nmid P<0.05$.

Mean values were significantly different from those of rats fed the blueberry husk diet: $\ddagger P<0.05$.

$\S$ For details of procedures and diets, see the Material and methods section and Table 2

$\|$ Body weight gain divided by the total feed intake during the experimental period.

I Median values and 25th to 75 th percentiles. 
Mann-Whitney rank sum test was used $(P<0 \cdot 05)$. Since the values of ammonia concentrations (Table 3 ) were not normally distributed, they are presented as medians and were evaluated using the Kruskal-Wallis test, followed by the Mann-Whitney rank sum test.

\section{Results}

\section{Feed intake and weight gain}

The rats appeared healthy and active throughout the experiment and the test diets were well tolerated. However, during anaesthesia one of the rats in the control group died. The rats consumed essentially all of the diet provided during the experimental period $(11.4-11.9 \mathrm{~g} / \mathrm{d}$; Table 3$)$. Significant differences were observed in body weight gain among the groups. When blueberry husks were included in the diet the rats gained more weight than those fed the control diet without any fibre $(0.44 \mathrm{~g} / \mathrm{g}$ feed $v .0 .37 \mathrm{~g} / \mathrm{g}$ feed, $P=0.043$; Table 3$)$. When the LABmix and BIFmix were added to the blueberry husk diet the rats gained less weight than rats fed the diet containing blueberry husks alone $(0.30 \mathrm{~g} / \mathrm{g}$ feed and $0.34 \mathrm{~g} / \mathrm{g}$ feed compared with $0.44 \mathrm{~g} / \mathrm{g}$ feed, $P=0.002$ and $P=0.020$, respectively).

\section{Bulking capacity and fermentability}

Addition of blueberry husks increased the mean faecal wet weight from 1.7 (SE 0.1 ) to $15.0(\mathrm{SE} 0.5) \mathrm{g} / 5 \mathrm{~d}$ and the mean dry weight from 1.5 (SE 0.0$)$ to 10.6 (SE 0.2) g/5 d (Table 4). The increase in faecal dry weight consisted largely of dietary fibre $(2.7 \mathrm{~g})$, but the amount of protein and fat also increased, by six and four times, respectively. The bulking capacity (faecal dry weight increment in $\mathrm{g}$ per $\mathrm{g}$ added fibre) in rats fed blueberry husks was 1.3 (Table 3 ). No further effects were seen on the faecal bulking capacity in rats when probiotics were added to the diets.

The dietary polysaccharides in blueberry husks were rather resistant to microbial degradation and $39 \%$ was excreted in faeces (Table 1). Glucose and xylose (xyloglucans) were most resistant to fermentation and on average $50 \%$ of the amount ingested was utilised by the microflora, while polymers containing uronic acids, galactose and arabinose were more fermented, and $27 \%$ was excreted in faeces of these compounds. No further effects on the fermentation of the fibre in blueberry husks were found when rats were fed the BIFmix or the LABmix (Table 3).

\section{Caecal tissue weight, content and $\mathrm{pH}$}

The weight of the caecal tissue was higher in rats fed the diet with blueberry husks and the control diet with BIFmix than in the control diet $(0.8$ and $0.6 \mathrm{~g} v .0 .4 \mathrm{~g}, P<0.05$; Table 3$)$. The caecal tissue weight was lower in rats given the blueberry husk and LABmix diet than in those given a diet containing blueberry husks alone $(0.7 \mathrm{~g} v .0 .8 \mathrm{~g}, P=0.002)$.

The weight of the caecum contents was higher in rats fed blueberry husks $(3.8 \mathrm{~g})$ than in those fed the control diet ( $3.8 \mathrm{~g} \mathrm{v.} 1.1 \mathrm{~g}, P<0.05$; Table 3 ). The addition of LABmix increased the weight of caecal contents when added to the control diet from 1.1 to $1.3 \mathrm{~g}(P=0.048)$, while it decreased the weight when added to the diet containing blueberry husks from 3.8 to $2.9 \mathrm{~g}(P=0.002)$.

The caecal $\mathrm{pH}$ varied between 6.7 and 7.2 (Table 3 ). Blueberry husks did not affect the caecal $\mathrm{pH}$, neither did the probiotics. However, a synergistic effect was seen when the BIFmix was given together with blueberry husks, leading to a lower $\mathrm{pH}$ than the control diet $(6 \cdot 7 v .7 \cdot 0, P<0 \cdot 014)$.

\section{Ammonia and urea in portal blood}

The BIFmix lowered the concentration of ammonia in portal blood (Table 3). The median concentration decreased from 0.49 (25 and 75 percentiles $0.36-0.65) \mu \mathrm{mol} / \mathrm{ml}$ to 0.32 $(0.30-0.40) \mu \mathrm{mol} / \mathrm{ml}(P=0.024)$ in rats fed the control diet. Similar effects were seen when the BIFmix was added to the blueberry husk diet, and the median ammonia concentrations decreased from 0.45 (25 and 75 percentiles $0.34-$ $0.82) \mu \mathrm{mol} / \mathrm{ml}$ to $0.33(0.28-0.49) \mu \mathrm{mol} / \mathrm{ml} \quad(P=0.042)$. No further effects on ammonia concentrations could be seen. No effects on the urea concentration were found with any of the test diets.

Table 4. Effect of blueberry husk and probiotic mixtures containing bifidobacteria (BIFmix) or lactobacilli (LABmix) on faecal output of rats§ (Mean values with their standard errors for nine rats per group)

Faecal dry wt $(\mathrm{g} / 5 \mathrm{~d})$

\begin{tabular}{|c|c|c|c|c|c|c|c|c|c|c|c|}
\hline & \multicolumn{2}{|c|}{$\begin{array}{l}\text { Dietary fibre } \\
\text { intake }(\mathrm{g} / 5 \mathrm{~d})\end{array}$} & \multicolumn{2}{|c|}{$\begin{array}{l}\text { Faecal wet wt } \\
\qquad(\mathrm{g} / 5 \mathrm{~d})\end{array}$} & \multicolumn{2}{|c|}{ Total } & \multirow{2}{*}{$\begin{array}{l}\text { Increment } \\
\text { Mean }\end{array}$} & \multirow{2}{*}{$\begin{array}{c}\text { Dietary fibre residue } \| \\
\text { Mean }\end{array}$} & \multirow{2}{*}{$\begin{array}{l}\text { Protein } \\
\text { Mean }\end{array}$} & \multirow{2}{*}{$\begin{array}{l}\text { Fat } \text { I } \\
\text { Mean }\end{array}$} & \multirow{2}{*}{$\begin{array}{l}\text { Ash } 1 \\
\text { Mean }\end{array}$} \\
\hline & Mean & SE & Mean & SE & Mean & $\overline{S E}$ & & & & & \\
\hline Control diet $(n 8)$ & - & - & $1 \cdot 5^{\mathrm{a}}$ & 0.1 & $1 \cdot 2^{\mathrm{a}}$ & 0.1 & - & - & 0.5 & 0.1 & 0.6 \\
\hline+ BIFmix & - & - & $1 \cdot 8^{\mathrm{a}}$ & 0.1 & $1 \cdot 6^{\mathrm{a}}$ & 0.1 & 0.3 & - & 0.6 & 0.2 & 0.6 \\
\hline + LABmix & - & - & $1.9^{\mathrm{a}}$ & 0.1 & $1 \cdot 6^{a}$ & 0.1 & 0.4 & - & 0.6 & 0.2 & 0.6 \\
\hline Blueberry husks & $7 \cdot 1^{\mathrm{a}}$ & 0.0 & $14 \cdot 0^{\mathrm{b}}$ & 0.5 & $10 \cdot 3^{b}$ & 0.3 & $9 \cdot 1$ & $2 \cdot 8$ & $3 \cdot 1$ & 0.6 & 0.8 \\
\hline+ BIFmix & $7 \cdot 1^{\mathrm{a}}$ & 0.0 & $15 \cdot 4^{b}$ & 0.5 & $10 \cdot 8^{b}$ & 0.1 & 9.6 & $2 \cdot 7$ & 3.2 & 0.6 & 0.8 \\
\hline+ LABmix & $6 \cdot 9^{b}$ & 0.0 & $15 \cdot 5^{\mathrm{b}}$ & 1.3 & $10 \cdot 7^{b}$ & 0.5 & 9.5 & $2 \cdot 7$ & 3.0 & 0.6 & 0.8 \\
\hline
\end{tabular}

BIFmix, Bifidobacterium infantis DSM15159 and DSM15161; LABmix, Lactobacillus crispatus DSM16743, L. gasseri DSM16737 and L. plantarum DSM15313.

${ }^{\mathrm{a}, \mathrm{b}}$ Mean values within a column with unlike superscript letters were significantly different $(P<0.05)$.

$\S$ For details of procedures and diets, see the Material and methods section and Table 2.

\| Values are means of the faecal excretion of dietary fibre monomers (i.e. lignin excluded).

I Pooled samples from eight (control) or nine rats. 
Table 5. Carboxylic acids in the hindgut of rats fed a control diet without any fibre, or a diet containing blueberry husks, and the same diets supplemented with bifidobacteria (BIFmix) or lactobacilli (LABmix)§ (Mean values with their standard errors for nine rats per group)

\begin{tabular}{|c|c|c|c|c|c|c|c|c|c|c|c|c|c|c|c|}
\hline & \multicolumn{2}{|c|}{$\begin{array}{l}\text { Control diet } \\
\quad(n 8)\end{array}$} & \multicolumn{2}{|c|}{$\begin{array}{l}\text { Control diet }+ \\
\text { BIFmix }\end{array}$} & \multicolumn{2}{|c|}{$\begin{array}{c}\text { Control diet }+ \\
\text { LABmix }\end{array}$} & \multicolumn{2}{|c|}{$\begin{array}{l}\text { Blueberry } \\
\text { husks }\end{array}$} & \multicolumn{2}{|c|}{$\begin{array}{c}\text { Blueberry } \\
\text { husks + BIFmix }\end{array}$} & \multicolumn{2}{|c|}{$\begin{array}{c}\text { Blueberry } \\
\text { husks + LABmix }\end{array}$} & \multicolumn{3}{|c|}{$P$} \\
\hline & Mean & SE & Mean & $\mathrm{SE}$ & Mean & SE & Mean & $\mathrm{SE}$ & Mean & $\mathrm{SE}$ & Mean & SE & Fibre & Pro & Fibre $\times$ Pro \\
\hline \multicolumn{16}{|l|}{ Caecum } \\
\hline Total $(\mu \mathrm{mol} / \mathrm{g})$ & $69^{a}$ & 6 & 65 & 5 & 81 & 3 & $55^{\mathrm{b}}$ & 3 & $41^{\star \star \star}$ & 2 & $29^{\star * *}$ & 1 & $<0.001$ & NS & $<0.001$ \\
\hline Total $(\mu \mathrm{mol} / \mathrm{caecal}$ content) & $75^{\mathrm{a}}$ & 7 & 72 & 10 & $106^{*}$ & 7 & $207^{\mathrm{b}}$ & 16 & $138^{\star \star \star}$ & 7 & $85^{\star \star \star}$ & 6 & $<0.001$ & $<0.001$ & $<0.001$ \\
\hline Acetic & $44^{\mathrm{a}}$ & 3 & 35 & 4 & 35 & 2 & $56^{\mathrm{b}}$ & 2 & 58 & 1 & 50 & 2 & $<0.001$ & $<0.05$ & NS \\
\hline Propionic & $14^{\mathrm{a}}$ & 1 & $10^{\star \star}$ & 1 & $11^{*}$ & 1 & $11^{\mathrm{b}}$ & 1 & 13 & 1 & $15^{\star \star}$ & 1 & NS & NS & $<0.001$ \\
\hline Butyric & 10 & 1 & $7^{*}$ & 1 & $7^{*}$ & 0 & 11 & 1 & 13 & 1 & 10 & 1 & $<0.001$ & NS & NS \\
\hline D-Lactic & 3 & 1 & $11^{\star \star}$ & 3 & 9 & 1 & 5 & 1 & 4 & 0 & 4 & 1 & $<0.05$ & $<0.05$ & $<0.001$ \\
\hline L-Lactic & $5^{a}$ & 1 & $10^{* \star *}$ & 2 & $8^{*}$ & 1 & $8^{\mathrm{b}}$ & 1 & 7 & 1 & 10 & 1 & NS & NS & NS \\
\hline Succinic & 15 & 4 & 22 & 4 & 25 & 2 & 7 & 1 & 3 & 1 & 8 & 2 & $<0.001$ & NS & NS \\
\hline Minor\| & $9^{a}$ & $\begin{array}{l}4 \\
1\end{array}$ & $5^{\star \star *}$ & 1 & $5^{\star \star *}$ & 0 & $2^{b}$ & 0 & $2^{*}$ & 0 & $3^{\star \star \star}$ & 0 & $<0.001$ & NS & $<0.001$ \\
\hline \multicolumn{16}{|l|}{ Proximal } \\
\hline Total $(\mu \mathrm{mol} / \mathrm{g})$ & 23 & 6 & $7^{\star}$ & 2 & 22 & 3 & 16 & 3 & 15 & 2 & 13 & 1 & NS & $<0.01$ & $<0.01$ \\
\hline \multicolumn{16}{|l|}{ Distalq } \\
\hline Total $(\mu \mathrm{mol} / \mathrm{g})$ & $15^{\mathrm{a}}$ & 2 & 13 & 1 & 15 & 1 & $10^{\mathrm{ab}}$ & 1 & 12 & 1 & 8 & 1 & $<0.001$ & NS & NS \\
\hline \multicolumn{16}{|l|}{ Faeces } \\
\hline Total $(\mu \mathrm{mol} / \mathrm{q})$ & $37^{\mathrm{a}}$ & 3 & $49^{\star}$ & 2 & $60^{\star \star \star}$ & 5 & $27^{\mathrm{b}}$ & 3 & 25 & 2 & 21 & 1 & $<0.001$ & $<0.05$ & $<0.001$ \\
\hline Total $(\mu \mathrm{mol} / \mathrm{d})$ & $25^{\mathrm{a}}$ & 2 & 33 & 5 & 29 & 6 & $139^{b}$ & 13 & 110 & 7 & 131 & 13 & $<0.001$ & NS & NS \\
\hline
\end{tabular}

BIFmix, Bifidobacterium infantis DSM15159 and DSM15161; LABmix, Lactobacillus crispatus DSM16743, L. gasseri DSM16737 and L. plantarum DSM15313.

a,b Mean values of control and blueberry husk only, i.e. those without any added probiotics, with unlike superscript letters were significantly different $(P<0.05)$.

Mean values were significantly different from those of rats fed diets without bacteria: ${ }^{\star} P<0.05,{ }^{* *} P<0.01,{ }^{* \star} P<0.001$.
$\S$ For details of procedures and diets, see the Material and methods section and Table 2 . Values are given as means of pools ( $\mu \mathrm{mol} / \mathrm{caecum}$ ) or concentrations ( $\mu$ mol/g) and standard errors or percentages of the total carboxylic acids.

ITrobulyic, isovaleric, valenic, caproic and heptanoic acid.

I The amount of lactic acid and succinic acid was not analysed due to insufficient material in the proximal and distal colon. 
Table 6. Concentration ( $\mu \mathrm{mol} / \mathrm{l})$ of SCFA in portal blood from rats fed a control diet without any fibre, or a diet containing blueberry husks, and the same diets supplemented with bifidobacteria (BIFmix) or lactobacilli (LABmix)§

(Mean values with their standard errors for nine rats per group)

\begin{tabular}{|c|c|c|c|c|c|c|c|c|c|c|c|c|c|c|c|}
\hline & \multicolumn{2}{|c|}{$\begin{array}{l}\text { Control diet } \\
\quad(n 8)\end{array}$} & \multicolumn{2}{|c|}{$\begin{array}{c}\text { Control } \\
\text { diet }+ \\
\text { BIFmix }\end{array}$} & \multicolumn{2}{|c|}{$\begin{array}{l}\text { Control } \\
\text { diet }+ \\
\text { LABmix }\end{array}$} & \multicolumn{2}{|c|}{$\begin{array}{l}\text { Blueberry } \\
\text { husks }\end{array}$} & \multicolumn{2}{|c|}{$\begin{array}{c}\text { Blueberry husks } \\
+ \text { BIFmix }\end{array}$} & \multicolumn{2}{|c|}{$\begin{array}{l}\text { Blueberry } \\
\text { husks }+ \\
\text { LABmix }\end{array}$} & \multicolumn{3}{|c|}{$P$} \\
\hline & Mean & SE & Mean & SE & Mean & SE & Mean & SE & Mean & SE & Mean & SE & Fibre & Pro & Fibre $\times$ Pro \\
\hline Acetic & 847 & 211 & 645 & 192 & $1394^{*}$ & 73 & 1158 & 121 & 1066 & 95 & 1297 & 75 & $<0.05$ & $<0.01$ & NS \\
\hline Propionic & 53 & 14 & 22 & 8 & 77 & 6 & 23 & 6 & $68^{\star \star}$ & 11 & $64^{\star \star}$ & 9 & NS & $<0.01$ & $<0.01$ \\
\hline Butyric & 13 & 4 & 5 & 2 & $31^{*}$ & 6 & 6 & 3 & $26^{\star \star}$ & 6 & $21^{\star *}$ & 6 & NS & $<0.01$ & $<0.01$ \\
\hline Isobutyric & 5 & 1 & 3 & 2 & $12^{\star \star \star}$ & 1 & 2 & 1 & $3^{*}$ & 0 & $8^{\star \star \star}$ & 1 & $<0.05$ & $<0.001$ & NS \\
\hline Isovaleric & $9^{\mathrm{a}}$ & 1 & 10 & 4 & $26^{\star \star \star}$ & 3 & $3^{b}$ & 1 & $8^{\star \star}$ & 1 & $17^{\star \star \star}$ & 2 & $<0.05$ & $<0.001$ & NS \\
\hline Valeric & $16^{\mathrm{a}}$ & 2 & 9 & 4 & 15 & 2 & $9^{b}$ & 5 & $26^{\star \star \star}$ & 3 & 11 & 1 & NS & NS & $<0.001$ \\
\hline Total & 942 & 232 & 695 & 211 & $1555^{\star}$ & 82 & 1202 & 122 & 1197 & 114 & 1419 & 85 & NS & $<0.01$ & NS \\
\hline
\end{tabular}

BIFmix, Bifidobacterium infantis DSM15159 and DSM15161; LABmix, Lactobacillus crispatus DSM16743, L. gasseri DSM16737 and L. plantarum DSM15313.

a,b Mean values of control and blueberry husk only, i.e. those without any added probiotics, with unlike superscript letters were significantly different $(P<0.05)$.

Mean values were significantly different from those of rats fed diets without bacteria: ${ }^{*} P<0.05,{ }^{* *} P<0.01,{ }^{* * *} P<0.001$.

$\S$ For details of procedures and diets, see the Material and methods section and Table 2.

\section{Carboxylic acids in the hindgut of rats}

Acetic acid was the major acid formed in the caecum of all the rats $(25-116 \mu \mathrm{mol})$ followed by propionic $(7-23 \mu \mathrm{mol})$ and butyric acid $(5-23 \mu \mathrm{mol})$ (Table 5). The relative mean distribution of acetic, propionic and butyric acids was 68,18 and $14 \%$, respectively, in the caecum, 79,13 and $8 \%$, respectively, in the proximal colon, and 64,20 and $16 \%$, respectively, in the distal colon.

The caecal pool of CA was higher in the rats fed blueberry husks than in those fed the control diet $(207 \mu \mathrm{mol} v .75 \mu \mathrm{mol}$, $P<0.05$; Table 5). This was due to an increase in all CA except the minor ones. The caecal proportion of acetic and L-lactic acid was higher $(P=0.002$ and $P=0.013)$ with blueberry husks, while that of propionic acid and all the minor acids was lower $(P=0.005$ and $P<0.001)$. Similar effects on the proportions of CA were seen in the proximal and distal parts of the colon, compared with caecum. An exception was the higher proportion of propionic acid in the distal part of colon (19\% v. $15 \%$ with the control diet, $P=0.05)$ and butyric acid in faeces $(12 \%$ v. $5 \%$ with the control diet, $P=0.05$ ) following the blueberry husk diet (data not shown in tables).

When the BIFmix or the LABmix was added to the blueberry husk diet, lower caecal concentrations $(55 \mu \mathrm{mol} / \mathrm{g} v$. 41 and $29 \mu \mathrm{mol} / \mathrm{g}$, respectively) and pools $(207 \mu \mathrm{mol} v .138$ and $85 \mu \mathrm{mol})$ of CA were seen $(P<0 \cdot 001)$. However, there was an increase in the caecal proportion of propionic and minor acids following the diet containing the LABmix $(P=0.007$ and $P<0.001)$ (Table 5).

When rats were fed the control diet, the caecal pools of CA increased when the LABmix was added to the diet (from 75 to $106 \mu \mathrm{mol}, P=0.023$ ), while the BIFmix had no effect (Table 5). The caecal proportions of most CA were lower with BIFmix and LABmix in the diet, with the exception of L-lactic acid, which was higher. A higher caecal proportion of D-lactic acid was also seen with BIFmix. A lower proportion of butyric and propionic acid was found in the proximal colon with BIFmix (2 and $4 \%$ v. 10 and $16 \%$, respectively), while the proportion of acetic acid was higher (81 v. 65\%) (data not shown in tables).

\section{SCFA in portal blood}

There was a comparatively high variation in SCFA concentration in serum among different individuals (Table 6). The major acid in portal blood was acetic acid (645-1394 $\mu \mathrm{mol} /$ 1) followed by propionic acid $(22-77 \mu \mathrm{mol} / \mathrm{l})$ and butyric acid $(5-31 \mu \mathrm{mol} / \mathrm{l})$ (Table 6). Considerable amounts of isobutyric $(2-12 \mu \mathrm{mol} / \mathrm{l})$, isovaleric $(3-26 \mu \mathrm{mol} / \mathrm{l})$ and valeric $(9-26 \mu \mathrm{mol} / \mathrm{l})$ acids were also detected. The average distribution between these acids was $92 \%$ (acetic acid), $4 \%$ (propionic acid) and $1 \%$ for each of the remaining acids.

The concentrations of SCFA in the portal blood of rats fed blueberry husks were similar to those fed the control diet; exceptions were isovaleric and valeric acid, which decreased. When LABmix or BIFmix were added to the blueberry husk diet an increase was seen in the mean concentrations of propionic (from 23 to $66 \mu \mathrm{mol} / \mathrm{l}$ ) and butyric acid (from 6 to $24 \mu \mathrm{mol} / \mathrm{l}) \quad(P<0 \cdot 01)$. The concentrations of isobutyric and isovaleric acid also increased $(P<0 \cdot 001)$. An increase in the concentration of valeric acid was seen with the BIFmix $(P<001)$.

When the LABmix was added to the control diet, the total concentration of SCFA increased in the serum of the rats $(P=0.039)$, due to an increase in the concentration of all these acids except propionic and valeric acid $(P<0.05$ to $P<0.001)$. BIFmix had no effect when added to the control diet.

\section{Bacteriology}

Adding the LABmix to the control diet resulted in an increase in the median viable counts of lactobacilli from 7.4 (25 and 75 percentiles 6.9-7.5) $\log \mathrm{CFU} / \mathrm{g}$ caecal tissue to $9.2(8.9-9.5)$ $\log \mathrm{CFU} / \mathrm{g}$ caecal tissue (Fig. 1 (A), $P<0.001$ ). A decrease in lactobacilli count was seen in all groups fed blueberry husks compared with the control diet $(P<0.05$ to $P<0 \cdot 01)$. L. plantarum DSM 15313 was found on the caecal tissue in the rats fed the LABmix, while L. crispatus DSM 16743 and $L$. gasseri DSM 16737 could not be detected. Different randomly amplified polymorphic DNA types of Lactobacillus originating from the resident flora of the animals were observed. 

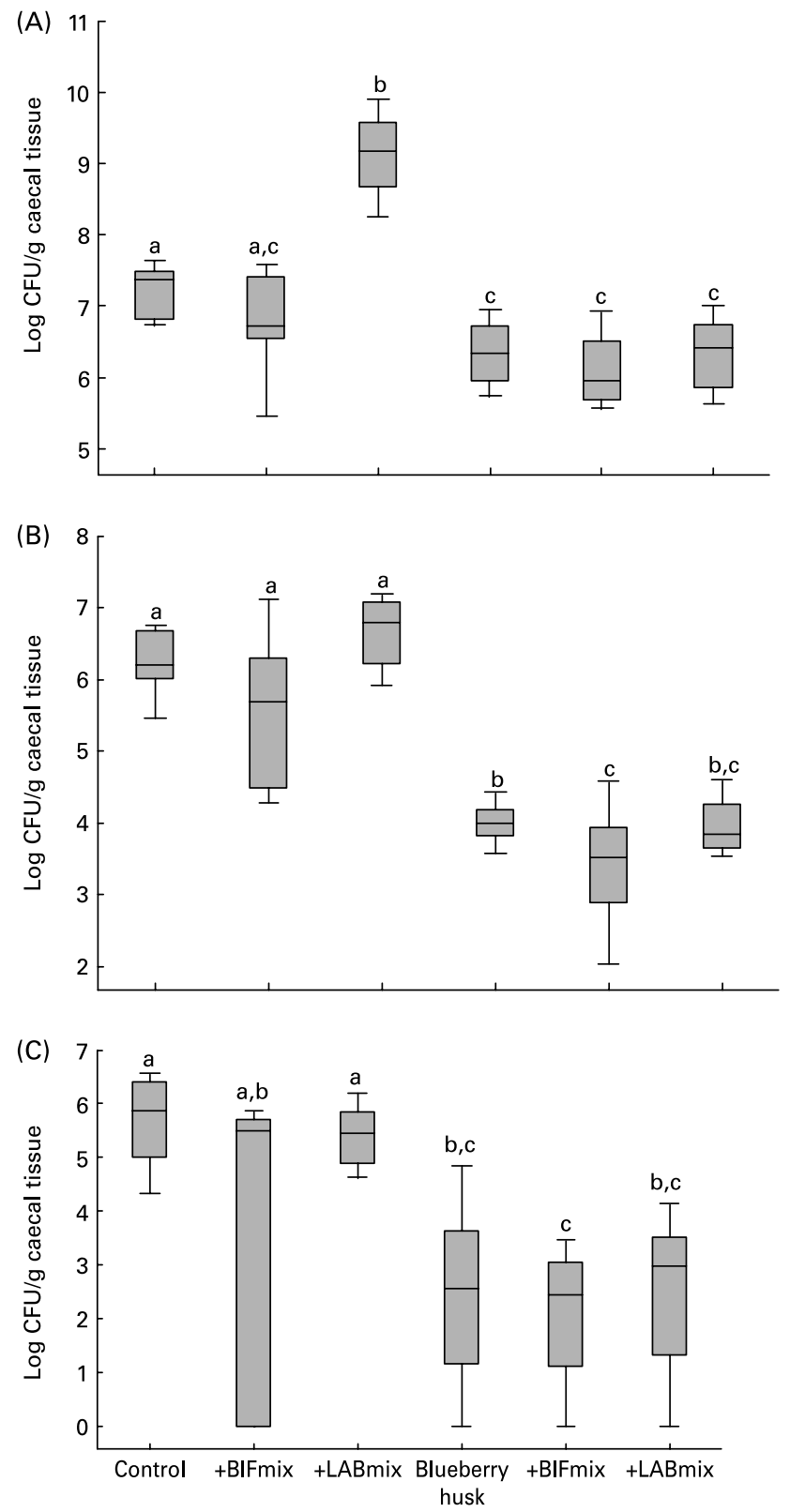

Fig. 1. Bacterial counts in caecum of rats fed different experimental diets: Lactobacillus (A), Bifidobacterium (B) and Enterobacteriaceae (C). Values are medians with 25 and 75 percentiles depicted by vertical bars. ${ }^{\text {a,b,c }}$ Groups with unlike superscript letters were significantly different $(P<0.05)$. BIFmix, Bifidobacterium infantis DSM15159 and DSM15161; CFU, colony-forming units; LABmix, Lactobacillus crispatus DSM16743, L. gasseri DSM16737 and L. plantarum DSM15313.

The addition of BIFmix to the diets did not increase the viable counts of bifidobacteria on rat caecum tissue. The median bifidobacteria count decreased in groups given blueberry husks alone, 4.0 (25 and 75 percentiles 3.9-4.2) $\log \mathrm{CFU} / \mathrm{g}$ tissue, and in combination with the BIFmix, 3.5 (3.0-3.8) $\log$ CFU/g tissue and together with the LABmix, 3.9 (3.7-4.2) $\log \mathrm{CFU} / \mathrm{g}$ tissue, compared with the control group, $6 \cdot 2$ (6.0-6.6) $\log$ CFU/g tissue (Fig. 1 (B), $P<0 \cdot 001$ ). A decrease in the bifidobacteria count was also seen in the caecum of rats fed blueberry husks together with the BIFmix, compared with rats fed blueberry husks without this mix $(P<0 \cdot 034)$.
The median viable counts of Enterobacteriaceae in caecum tissue were reduced in the groups given blueberry husk alone, 2.6 (25 and 75 percentiles 1.8-3.6) $\log$ CFU/g tissue, and in combination with the BIFmix, $2.4(1.7-3 \cdot 0) \log$ CFU/g tissue, or the LABmix, $3.0(2 \cdot 0-3 \cdot 5) \log C F U / g$ tissue, compared with the control group, $5.9(5 \cdot 1-6 \cdot 3) \log \mathrm{CFU} / \mathrm{g}$ tissue (Fig. 1 (C), $P<0 \cdot 001$ ).

\section{Discussion}

The present results demonstrate that intestinal fermentation characteristics were affected by blueberry husks, by different multi-strain mixtures of probiotics, and by combinations of blueberry husks and probiotics. Different combinations were shown to have different effects.

The dietary polysaccharides in blueberry husks were rather resistant to microbial degradation and $39 \%$ was excreted in faeces. This high resistance to fermentation may be due to the high content of lignin, measured as Klason lignin ( $144 \mathrm{~g} / \mathrm{kg}$, dry weight basis), including not only lignin but also other polyphenols ${ }^{(33)}$. Other food items containing high amounts of lignin, such as wheat bran, have also been reported to be quite resistant to fermentation. However, the bulking capacity of blueberry husks was higher than that of wheat bran, $1.3 \mathrm{~g} / \mathrm{g}$ fibre $v .1 .0 \mathrm{~g} / \mathrm{g}$ fibre for wheat $\operatorname{bran}^{(34)}$, i.e. as high as with certain commercial bulk laxatives ${ }^{(35)}$. Polyphenols in blueberries have also been reported to reach colon and may have contributed to the bulking effect ${ }^{(4)}$. The faecal excretion of protein and fat increased on average by six and four times, respectively, with blueberry husks. The amount of fat excreted by the rats was similar to previously reported values with different types of fibre, while the amount of protein was considerably higher than in previous studies ${ }^{(23,35)}$. It may be speculated whether the polyphenols in the blueberry husks inhibit the digestion of protein. An interaction between tannins and proteins has been shown to cause a reduction in net protein utilisation ${ }^{(36)}$, and similar effects have also been found in rats after a high intake of phenolic compounds ${ }^{(37)}$.

The caecal content of CA in rats fed blueberry husks was, as expected, higher than without this fibre source. However, the content was comparatively low, and in the same range as previously reported with wheat bran ${ }^{(38)}$. Furthermore, the caecal proportions of acetic, propionic and butyric acids were similar to those with wheat bran ${ }^{(39)}$. The proportions of propionic acid and butyric acid were higher in the distal colon and faeces, respectively, in rats fed blueberry husks than in rats fed the fibre-free control diet (data not shown). This is important, as both these acids are essential substrates for the colonic epithelial cells, improving gut health, and a surplus of substrates also has metabolic effects.

The caecal pool of succinic acid was higher in rats fed blueberry husks than in rats fed the fibre-free diets. Blueberry husk has antimicrobial effects, as judged by the decreased counts of lactobacilli, bifidobacteria and Enterobacteriaceae and the larger pool of succinic acid may be a consequence of these antimicrobial effects. An increase in succinic acid concentration in rats treated with broad-spectrum antibiotics has been reported ${ }^{(40)}$.

The concentration of CA in the caecum of rats given blueberry husks together with either of the probiotic mixtures was lower than with blueberry husks alone $(P<0 \cdot 001)$. This may be due 
to enhanced absorption in the presence of probiotics, but it cannot be excluded that the viable probiotics may have been stimulating the fermentation to start already in the small intestine ${ }^{(41)}$, contributing to the lower concentration. Interestingly, the absorption of specific acids may have been facilitated, as judged by the higher concentration of propionic and butyric acids in serum of rats. This must be considered positive, as it is important to improve both the nutritional status of the mucosa ${ }^{(42)}$ and the concentration of these SCFA in blood $^{(10,43)}$. Surprisingly, the concentration of SCFA in portal blood was higher in rats fed the control diet than those fed the diet with blueberry husks. It may be speculated whether this was due to the higher permeability in the hindgut of the rats, since smaller amounts of SCFA are formed due to the absence of fibre. Further, the shorter transit time through the colon with the fibre-rich blueberry husks may have contributed to this effect.

When the diets were supplemented with the LABmix, the caecal content increased in the case of the fibre-free diet $(P<0.048)$ but decreased when added to the blueberry husk $\operatorname{diet}(P<0.002)$. The increased caecal content in rats fed the control diet containing LABmix may be due to an increase in the number of lactobacilli and an increased amount of bacterial polysaccharides and perhaps also stimulation of synthesis of endogenous polysaccharides. The decrease in caecal contents in rats fed blueberry husks and LABmix compared with those fed blueberry husks alone may be due to the fact that the dietary fibre polysaccharides and/or polyphenols were degraded by the colonic microbiota, to a higher extent in the presence of LABmix. Another explanation could be that weak bonds between molecules were broken by the LABmix changing the three-dimensional structure, and as a consequence less water was retained in the caecum. In view of the fact that the degree of fermentation and the bulking capacity were very similar regardless of whether probiotics were added to the blueberry husk diet or not, modification of the architecture of the fibre by the LABmix seems to be a probable explanation.

The caecal tissue weight has been shown to be correlated to the caecal content, and not to the formation of $\mathrm{CA}$, in many studies $^{(44)}$. This was also shown in the present study; the exception being rats fed a fibre-free diet with the BIFmix, where the caecal tissue weight was higher than expected. The reason for this is not known, but the appearance of the caecal tissue was considerably different (swollen) from that of rats fed the other diets. It may be speculated whether this fact influenced the absorption of SCFA, since rats fed the fibre-free diet containing the BIFmix showed the lowest concentrations of SCFA in serum.

The probiotic supplementations influenced the body weight gain. The weight gain in rats fed blueberry husks and BIFmix or LABmix were lower than those fed blueberry husks only. In the case of LABmix and blueberry husks the body weight gain was at least partly influenced by the caecal content, which was lower in these rats than those fed blueberry husks only. However, since there was no difference in caecal content between rats fed BIFmix and those fed blueberry husks only, the lower body weight gain may be due to a lower muscular and/or fat weight. Further, no data on muscular and fat weight were obtained in the present study. The caecum content seems also to be the cause of the higher weight gain in rats fed blueberry husks compared with the control group. Another explanation may be the formation of CA per se, produced during fermentation of blueberry husks, increasing the nutritional status and the weight of the caecal tissue. Fructo-oligosaccharides, which give high amounts of CA during fermentation and have the capacity to increase the number of bifidobacteria, have been reported to reduce the plasma concentrations of endotoxins (lipopolysaccharides) ${ }^{(45)}$. This observation was explained by a lower permeability of the mucosa.

None of the diets was able to increase significantly the number of bifidobacteria. The result was surprising, in view of the fact that the BIFmix contained viable B. infantis. This may be explained by an antagonistic effect exerted by the exogenous bifidobacteria against the resident microbiota, affecting the composition of different Bifidobacterium spp. present in the intestines. Another possible mechanism may be the viable count on selective media method, which is a somewhat unreliable technique. However, a third explanation could be that consuming Bifidobacterium may induce an immunological response in the host directed directly or indirectly towards bifidobacteria.

Ingestion of blueberry husks was accompanied by a decrease in the number of Enterobacteriaceae. This must be regarded as beneficial because the Enterobacteriaceae family includes many potential pathogens with urease activity, which can contribute to their virulence and enhance their acid resistance $^{(46)}$, and they also possess highly potent endotoxins. The beneficial effect may be mediated by the high antimicrobial effect of the polyphenols in blueberry husks.

In the present study, the BIFmix alone and in combination with blueberry husks reduced the concentration of ammonia in the portal vein compared with rats fed the control diet. In earlier studies Bifidobacterium spp. have been found to use ammonia as the nitrogen source for their growth ${ }^{(47)}$, thus reducing the concentration of ammonia in the portal vein ${ }^{(48)}$. This is of interest, since control of the ammonia concentration is a serious problem in patients with liver disease, where circulating ammonia concentrations are high as a result of impaired liver function and decreased urea synthesis.

In conclusion, due to the relatively high resistance to colonic fermentation blueberry husks gave a rather low amount of CA. The amount of CA in caecum was influenced by the probiotic mixtures, either by an enhanced absorption in caecum to the portal vein, or by stimulating the fermentation in the small intestine. In either case, the concentration of propionic and butyric acid in serum was higher with the probiotic mixtures, implying that the absorption of these acids was facilitated by the bacteria. Another interesting result was the BIFmix impact on ammonia concentration, of lowering it. These significant differences were found even though the blueberry husks showed to be antimicrobial and no significant elevations of lactobacilli or bifidobacteria were found in the groups given either of the two probiotic mixtures together with blueberry husks. The blueberry husks were shown to have trophic effects on caecal tissue, which may be due to the high caecal content or by the nutritional stimulation from the CA formed in the caecum. Further, this high caecal tissue weight and caecal content may presumably have influenced the higher weight gain found in blueberry husks compared with the control group, despite the fact that the faecal excretion of protein and fat were higher in rats fed blueberry husks than in those fed the fibre-free control diet. 


\section{Acknowledgements}

This study was financed by the Functional Food Science Centre (FFSC) at Lund University. We would like to thank Probi AB (Lund, Sweden) for kindly supplying the freeze-dried blueberry husks. None of the authors had a conflict of interest. C. B. and $\AA$. H. contributed equally to the work. All of the authors took part in the design of the study, the evaluation of the results and the writing of the manuscript. C. B. and $\AA$. H. performed the animal experiment and the experimental work, and were responsible for the writing of the manuscript.

\section{References}

1. Collins MD \& Gibson G (1999) Probiotics, prebiotics, and synbiotics: approaches for modulating the microbial ecology of the gut. Am J Clin Nutr 69, 1052S-1057S.

2. Volker M (2004) Dietary modification of the intestinal microbiota. Nutr Rev 62, 235-242.

3. Wong J, de Soouza R, Kendell C, Emam A \& Jenkins D (2006) Colonic health: fermentation and short chain fatty acids. J Clin Gastroenterol 40, 235-243.

4. Kahle K, Kraus M, Scheppach W, Ackermann M, Ridder F \& Richling E (2006) Studies on apple and blueberry fruit constituents: do the polyphenols reach the colon after ingestion? Mol Nutr Food Res 50, 418-423.

5. Gibson GR \& Roberfroid MB (1995) Dietary modulation of the human colonic microbiota: introducing the concept of prebiotics. J Nutr 125, 1401-1412.

6. Ruppin H, Bar-Meir S, Soergel KH, Wood CM \& Schmitt MGJ (1980) Absorption of short-chain fatty acids by the colon. Gastroenterology 78, 1500-1507.

7. Roediger WE (1982) Utilization of nutrients by isolated epithelial cells of the rat colon. Gastroenterology 83, 424-429.

8. Schwartz B \& Avivi-Green C (1998) Sodium butyrate induces retinoblastoma protein dephosphorylation, p16 expression and growth arrest of colon cancer cell. Mol Cell Biochem 188, 21-30.

9. Bach Knudsen KE, Serena A, Canibe N \& Juntunen KS (2003) New insight into butyrate metabolism. Proc Nutr Soc 62, 81-86.

10. Wolever TM, Spadafora P \& Eshuis H (1991) Interaction between colonic acetate and propionate in humans. Am J Clin Nutr 53, 681-687.

11. Mink PJ, Scrafford CG, Barraj LM, Harnack L, Hong C-P, Nettleton JA \& Jacobs DR Jr (2007) Flavonoid intake and cardiovascular disease mortality; a prospective study in postmenopausal women. Am J Clin Nutr 85, 895-909.

12. Rice-Evans CA, Miller NJ \& Paganga G (1996) Structure-antioxidant activity relationships of flavonoids and phenolic acids. Free Radic Biol Med 20, 933-956.

13. Scalbert A (1991) Antimicrobial properties of tannins. Phytochemistry 30, 3875-3883.

14. Osawa R, Kuroiso K, Goto S \& Shimizu A (2000) Isolation of tannin-degrading lactobacilli from humans and fermented foods. Appl Environ Microbiol 66, 3093-3097.

15. Barthelmebs L, Divies C \& Calvin J-F (2000) Knockout of the p-coumarate decarboxylase gene from Lactobacillus plantarum reveals the existence of two other inducible enzymatic activates involved in phenolic acid metabolism. Appl Environ Microbiol 66, 3368-3375.

16. Puupponen-Pimiä R, Nohynek L, Meier C, Kähkönen M, Heinonen M, Hopia A \& Oksman-Caldentey K-M (2001) Antimicrobial properties of phenolic compounds from berries. J Appl Microbiol 90, 494-507.

17. Häkkinen $S$ (2000) Flavonols and phenolic acids in berries and berry products. PhD Thesis, Kuopio University
18. Bäckhed F, Ding H, Wang T, Hopper LV, Koh Young G, Nagy A, Semenkovich CF \& Gordon JI (2004) The gut microbiota as an environmental factor that regulates fat storage. Proc Natl Acad Sci U S A 101, 15718-15723.

19. Ley RE, Bäckhed F, Turnbaugh PJ, Lozupone CA, Knight RD \& Gordon JI (2005) Obesity alters gut microbial ecology. Proc Natl Acad Sci U S A 102, 11070-11075.

20. Turnbaugh PJ, Ley RE, Mahowald MA, Magrini V, Mardis ER \& Gordon JI (2006) An obesity-associated gut microbiome with increased capacity for energy harvest. Nature 444, 1027-1031.

21. Efthymiou C \& Hansen C (1962) An antigenic analysis of Lactobacillus acidophilus. J Infect Dis 110, 258-267.

22. Matteuzzi D, Crociani F \& Emaldi O (1978) Amino acids produced by bifidobacteria and some Clostridia. Ann Microbiol 129B, 175-181.

23. Nyman M \& Asp NG (1982) Fermentation of dietary fibre components in the rat intestinal tract. Br J Nutr 47, 357-366.

24. Björck I, Nyman M, Pedersen B, Siljeström M, Asp N-G \& Eggum B (1987) Formation of enzyme resistant starch during autoclaving of wheat starch: studies in vitro and in vivo. $J$ Cereal Sci 6, 159-172.

25. Nyman M \& Asp NG (1985) Dietary fibre fermentation in the rat intestinal tract: effect of adaptation period, protein and fibre levels, and particle size. Br J Nutr 54, 635-643.

26. Asp N-G, Johansson C-G, Hallmer H \& Siljeström M (1983) Rapid enzymatic assay of insoluble and soluble dietary fiber. J Agric Food Chem 31, 476-482.

27. Theander O, Aman P, Westerlund E, Andersson R \& Pettersson D (1995) Total dietary fiber determined as neutral sugar residues, uronic acid residues, and Klason lignin (the Uppsala method): collaborative study. J AOAC Int 78, 1030-1044.

28. Zhao G, Liu J-f, Nyman M \& Jönsson JÅ (2007) Determination of short-chain fatty acids in serum by hollow fiber supported liquid membrane extraction coupled with gas chromatography. J Chromatogr 846, 202-208.

29. Zhao G, Nyman M \& Jönsson JÅ (2006) Rapid determination of short-chain fatty acids in colonic contents and faeces of humans and rats by acidified water-extraction and direct-injection gas chromatography. Biomed Chromatogr 20, 674-682.

30. Stenberg M, Marko-Varga G \& Öste R (2002) Enantioseparation of $\mathrm{D}$ - and $\mathrm{L}$-amino acids by a coupled system consisting of an ion-exchange column and a chiral column and determination of D-aspartic acid and D-glutamic acid in soy products. Food Chem 79, 507-512.

31. Rada V (2000) Petr J A new selective medium for the isolation of glucose nonfermenting bifidobacteria from hen caeca. J Microbiol Methods 43, 127-132.

32. Quednau M, Ahrné S, Peterson A \& Molin G (1998) Identification of clinically important species of Enterococcus within 1 day with randomly amplified polymorphic DNA (RAPD). Curr Microbiol 36, 332-336.

33. Lecumberri E, Mateos R, Ramos S, Alia M, Ruperez P, Goya L, Izquierdo-Pulido M \& Bravo L (2006) Characterization of cocoa fiber and its effect on the antioxidant capacity of serum in rats. Nutr Hosp 21, 622-628.

34. Nyman M (2002) Fermentation and bulking capacity of indigestible carbohydrates: the case of inulin and oligofructose. $\mathrm{Br} \mathrm{J}$ Nutr 87, Suppl. 2, S163-S168.

35. Nyman M \& Asp NG (1985) Bulk laxatives: their dietary fibre composition, degradation, and faecal bulking capacity in the rat. Scand J Gastroenterol 20, 887-895.

36. Haslam E (1981) Vegetable tannins. In The Biochemistry of Plants, pp. 527-556 [E Conn, editor]. New York: Academic Press.

37. Moseley G \& Griffiths DW (1979) Varietal variation in the antinutritive effects of field beans (Vicia faba) when fed to rats. $J$ Sci Food Agric 30, 772-778. 
38. Henningsson ̊M, Björck IM \& Nyman EM (2002) Combinations of indigestible carbohydrates affect short-chain fatty acid formation in the hindgut of rats. J Nutr 132, 3098-3104.

39. Berggren AM, Björck IME \& Nyman EMG (1993) Short-chain fatty acid content and $\mathrm{pH}$ in caecum of rats given various sources of carbohydrates. J Sci Food Agric 63, 397-406.

40. Berggren AM (1996) Formation, pattern and physiological effects of short-chain fatty acids. PhD Thesis, Lund University.

41. Bering S, Sjoltov L, Wrisberg SS, Berggren A, Alenfall J, Jensen M, Hojgaard L, Tetens I \& Bukhave K (2007) Viable, lyophilized lactobacilli do not increase iron absorption from a lactic acid-fermented meal in healthy young women, and no iron absorption occurs in the distal intestine. Br J Nutr 98, 991-997.

42. Roediger WE (1990) The starved colon-diminished mucosal nutrition, diminished absorption, and colitis. Dis Colon Rectum 33, 858-862.

43. Marcil V, Delvin E, Seidman E, Poitras L, Zoltowska M, Garofalo C \& Levy E (2002) Modulation of lipid synthesis, apolipoprotein biogenesis, and lipoprotein assembly by butyrate. Am J Physiol Gastrointest Liver Physiol 283, G340-G346.

44. Wyatt GM, Horn N, Gee JM \& Johnson IT (1988) Intestinal microflora and gastrointestinal adaptation in the rat in response to non-digestible dietary polysaccharides. Br J Nutr 60, 197-207.

45. Cani PD, Neyrinck AM, Fava F, Knauf C, Burcelin RG, Tuohy KM, Gibson GR \& Delzenne NM (2007) Selective increases of bifidobacteria in gut microflora improve high-fat-diet-induced diabetes in mice through a mechanism associated with endotoxaemia. Diabetologia 50, 2374-2383.

46. Mobley HL, Island MD \& Hausinger RP (1995) Molecular biology of microbial ureases. Microbiology 59, 451-480.

47. Hassinen JB, Durbin GT \& Tomarelli Bernhart FW (1951) The minimal nutritional requirements of Lactobacillus bifidus. J Bacteriol 62, 771-777.

48. Deguchi Y, Makino K, Iwabuchi A, Watanuki M \& Yamashita $\mathrm{T}$ (1993) Selection of ammonia-assimilating bifidobacteria and their effect on ammonia levels in rat caecal contents and blood. Microb Ecol Health Dis 6, 85-94. 